\title{
Power Generation Technology Options for a Mars Mission
}

John M. Bozek and Robert L. Cataldo

Lewis Research Center

Cleveland, Ohio

Prepared for the

Symposia on Space Nuclear Power Systems

sponsored by the University of New Mexico

Albuquerque, New Mexico, January 9-13, 1994 


\title{
POWER GENERATION TECHNOLOGY OPTIONS FOR A MARS MISSION
}

\author{
John M. Bozek and Robert L. Cataldo \\ National Aeronautics and Space Administration \\ Lewis Research Center \\ Cleveland, Ohio 44135
}

\section{SUMMARY}

The power requirements and resultant power system performances of an aggressive Mars mission are characterized. The power system technologies discussed will support both cargo and piloted space transport vehicles as well as a six-person crew on the martian surface for 600 days. The mission uses materials transported by cargo vehicles and materials produced using in-situ planetary feed stock to establish a life-support cache and infrastructure for the follow-on piloted lander. Numerous power system technical options are sized to meet the mission power requirements using conventional and novel solar, nuclear, and wireless power transmission technologies for stationary, mobile surface, and space applications. Technology selections will depend on key criteria such as mass, volume, area, maturity, and application flexibility.

\section{INTRODUCTION}

NASA is currently in the process of identifying and quantifying mission architectures and technology options for a manned Mars mission. The baseline mission architecture envisions landing six astronauts on the martian surface by the first decade of the next century and providing the capability for in-situ production, bioregenerative life support, surface habitation and mobility, emergency power, and lift-off propellants for Earth return. These goals will be accomplished with a range of power system options that use both conventional and novel technologies to satisfy these diverse requirements.

This report provides a brief description of the current mission requirements and presents a preliminary performance evaluation of a variety of space and surface power technology options from the standpoint of power system mass, volume, and deployed area.

\section{MISSION REQUIREMENTS}

The mission architecture calls for a "split" mission concept in which cargo and piloted vehicles are launched separately. A series of three cargo vehicles will be launched to Mars in 2-month intervals starting in late 2007. The cargo vehicles will have sufficient material and power capability to autonomously emplace an infrastructure capable of supporting six astronauts. Upon confirmation that the infrastructure and a cache of life-supporting, in-situ products are in place, a piloted Mars transfer vehicle (MTV) will follow at the next opportunity.

The first two cargo vehicles will deliver a habitat, a bioregenerative chamber for food production, a plant to produce water, a plant to produce methane and oxygen, oxygen and buffer gases, two unpressurized rovers, one pressurized rover, the power system(s) with cable-captive or wireless power transmission, and cache storage capabilities to the martian surface. The third cargo vehicle will deliver the Earth retum vehicle (ERV) to martian orbit where it will remain awaiting crew ascent, rendezvous, and subsequent trans-Earth insertion. The piloted MTV contains a transit habitat that is ultimately placed on the martian surface with the six astronauts inside. This transit habitat will expand the livable quarters on the surface beyond that available through a previous cargo vehicle landing.

Table I shows the current mission power and duration requirements of the space and surface application elements. Space elements include the cargo and piloted vehicles required to accomplish the Earth-Mars surface-Earth transition; surface mission elements include life support, in-situ resource utilization, rovers, and methane production. 
Three of the surface infrastructure elements that may use methane-based power are the habitat/bioregenerative chamber and both manned rovers. In the event of a power system failure for the habitat/bioregenerative chamber, the methane-based power system is a possible source of emergency backup power. A 5- and a 60-day emergency period were analyzed.

Space power levels range from $2.5 \mathrm{kWe}$ for the cargo vehicle to $30 \mathrm{kWe}$ for the manned MTV and ERV, and durations range from minutes to hundreds of days. While awaiting arrival of the crew in Mars orbit, the ERV is designated as an orbiter and requires $5 \mathrm{kWe}$ for 515 days.

Individual surface elements require power levels up to $120 \mathrm{kWe}$ with durations ranging from hours to years. However, in some instances, because of the anticipated proximity of these elements and the potential centralized power system capability, selected mission elements have been combined to create a higher load requirement. These combinations will be discussed in the Technology Options section.

The 10-kWe pressurized rover will be capable of $500 \mathrm{~km}$ sorties lasting 20 days with two to three astronauts on board. The two 4-kWe unpressurized rovers will only operate for 10 daylight hours, with a range of 15 to $20 \mathrm{~km}$ per sortie.

The in-situ resource utilization (ISRU) plant will produce a cache of water, oxygen, and buffer gases for crew life support. The ISRU plant will be capable of several separate processes powered by a single 120 -kWe power plant and will produce a 600 -day life support prior to the arrival of the crew on the martian surface.

The methane plant produces a cache of methane and oxygen that can provide propellants for Mars surface liftoff capability or for an energy source for the habitat, bioregenerative chamber, and rovers. The manufacturing process uses hydrogen imported from Earth and in-situ carbon dioxide from Mars' atmosphere to produce water and methane. Electrolysis of water produces usable oxygen and recyclable hydrogen. A $40-\mathrm{kWe}$ plant can produce sufficient products to provide up to 60 days of emergency power for the habitat and bioregenerative chamber, and can produce 4 and $10 \mathrm{kWe}$ for the unpressurized and pressurized rovers, respectively.

\section{TECHNOLOGY OPTIONS}

The power technologies examined included systems for operational power in table II and methane-based power in table III. Both tables display the mass, deployed area, volume, power system application, and required power level of these technologies. Reactor- and isotope-based power systems comprise the nuclear technologies, and photovoltaic arrays and solar concentrators, with and without energy storage, comprise the nonnuclear category, including primary electrochemical energy storage.

Nuclear reactor power systems are based on SP-100 reactors and Stirling cycle thermal-to-electric conversion technologies; however, over the range of power levels shown, the mass, area, and volume values are representative of other SP-100 systems using Brayton or thermoelectric conversion. Reactor power systems have been used to provide operational power for multiple load applications. For these applications, all reactor power systems have been arbitrarily located $2 \mathrm{~km}$ away from the nearest load. In addition, reactor power systems include an integral $4 \pi$ radiation shield designed to limit human exposure to $5 \mathrm{rem} / \mathrm{yr}$ at a distance of $2 \mathrm{~km}$.

The largest multiple load application $(270 \mathrm{kWe})$ was powered by a $520-\mathrm{kWe}$ SP-100/Stirling cycle power system using a wireless power transmission system based on microwave technology. Discounting the increased load requirement discussed below, a key feature of this concept is that the location of loads and the power system are not constrained by a fixed cable length. The $270-\mathrm{kWe}$ total load for this power system includes the methane and ISRU plants, a habitat/bioregenerative chamber, and an additional $25-\mathrm{kWe}$ habitat to quantify the extent to which diverse loads can be accommodated. All loads can be located at diverse locations up to $14 \mathrm{~km}$, the maximum line- 
of-sight distance for a 10-m-high antenna and a 5-m-high rectenna. The wireless transmission power system includes a $20000-\mathrm{kg}, 520-\mathrm{kWe}$ SP-100/Stirling power generator and a $5400-\mathrm{kg} 100-\mathrm{GHz}$ microwave transmitter subsystem with individual antennas and rectennas for each load. The other multiple load application of $160 \mathrm{kWe}$ is supplied by a $180-\mathrm{kWe}$ SP-100/Stirling cycle power system using a high-voltage insulated cable transmission.

The nuclear dynamic isotope power systems (DIPS) are based on general purpose heat source (GPHS) technology with small Stirling cycle engines. DIPS-powered space and surface applications were limited to low power levels with high energy requirements to limit the Earth launch inventory of plutonium. The human-rated gamma radiation shield for rover applications was sized to limit exposure to $5 \mathrm{rem} / \mathrm{yr}$ whereas the cargo vehicle application did not require a shield. Also, the potential portability of a DIPS could permit additional operational or emergency applications, such as habitat emergency power.

The solar-based power systems include a range of photovoltaic (PV) technology options for surface and space applications and a solar dynamic (S/D) option for space applications only. Photovoltaic system options using GaAs cell technology have been considered with fixed, tracking, and tent arrays. Electrochemical storage options included high-energy-density NaS batteries for short-duration applications and $\mathrm{H}_{2} / \mathrm{O}_{2}$ regenerative fuel cells (RFC) for longduration applications. A nonregenerative $\mathrm{H}_{2} / \mathrm{O}_{2}$ primary fuel cell (PFC) was also considered for the short sortie and daylight-only requirement for the unpressurized rover.

Methane-based power applications and technologies use the previously stored methane and oxygen cache to generate electricity with three different conversion options (table III) and the Stirling cycle option uses external combustion of methane and oxygen. The proton exchange membrane fuel cell (PEM FC) and solid oxide fuel cell (SOFC) technologies use an $\mathrm{H}_{2}$ reformer. The hydrogen is then combined with oxygen to operate the fuel cell. The mass and volume of these options are strongly dependent on the operating duration of the specific application because of reactant storage tank requirements.

\section{CONCLUDING REMARKS}

This report has presented preliminary estimates of the mass, volume, and deployed area for many power system technologies as applied to numerous discrete elements of a manned Mars mission. Selection of a power system technology for a specific mission element will depend on further mission requirements and power system design definitions. Even though the down selection to fewer technologies may be desirable, it may be premature, given the technology maturation rate, the ever-changing political environment, and flux of mission requirements. In fact, the power system technology trade-space may have to be expanded as technologies emerge from the laboratory.

\section{ACKNOWLEDGMENTS}

We wish to thank all those who have contributed their time, talent, and energies in establishing an impressive power system data base. These dedicated and creative individuals are Jeffrey George, Thomas Maloney, Nelson Morales, Marla Perez-Davis, Michael Piszczor, and Colleen Withrow, of NASA Lewis Research Center; Anthony Colozza, Miles Dustin, Paul Schmitz, Daniel Soltis, and Mark Stavnes, of Sverdrup Technology, Inc. 
TABLE I-SPACE AND SURFACE ELEMENT REQUIREMENTS

\begin{tabular}{|c|c|c|c|c|c|}
\hline Space mission element & $\begin{array}{c}\text { Power, } \\
\text { kWe }\end{array}$ & Duration & Surface mission element & $\begin{array}{c}\text { Power, } \\
\text { kWe }\end{array}$ & Duration \\
\hline $\begin{array}{l}\text { Cargo vehicle } \\
\text { Earth orbit } \\
\text { Trans-Mars insertion } \\
\text { Cruise to Mars orbit } \\
\text { Mars orbit insertion } \\
\text { Mars orbit to Mars surface } \\
\text { Mars tranfer vehicle (MTV) } \\
\text { Earth orbit } \\
\text { Trans-Mars insertion } \\
\text { Cruise to Mars orbit } \\
\text { Mars orbit insertion } \\
\text { Earth return vehicle (ERV) } \\
\text { Trans-Earth insertion } \\
\text { Cruise to Earth orbit } \\
\text { Earth orbit insertion } \\
\text { Earth orbit to Earth surface } \\
\text { Orbiter (part of ERV) } \\
\text { Mars orbit }\end{array}$ & $\begin{array}{c}2.5 \\
2.5 \\
2.5 \\
2.5 \\
\text { (a) } \\
\\
30 \\
30 \\
30 \\
30\end{array}$ & $\begin{array}{c}5 \text { days } \\
2 \text { hr } \\
339 \text { days } \\
2 \mathrm{hr} \\
\text { (a) } \\
1 \text { day } \\
30 \text { min } \\
180 \text { days } \\
11 \text { min } \\
10 \text { min } \\
180 \text { days } \\
\text { (a) } \\
\text { (a) } \\
515 \text { days }\end{array}$ & $\begin{array}{l}\text { In-situ resource utilization } \\
\text { ISRU plant } \\
\text { ISRU storage } \\
\text { Methane plant } \\
\text { Methane plant storage }\end{array}$ & $\begin{array}{c}120 \\
6 \\
40 \\
1.3\end{array}$ & $\begin{array}{c}2 \mathrm{yr} \\
>6 \mathrm{yr} \\
1 \mathrm{yr} \\
\text { As needed }\end{array}$ \\
\hline
\end{tabular}

${ }^{3}$ To be determined. 
TABLE II-OPERATIONAL TECHNOLOGIES

\begin{tabular}{|c|c|c|c|c|c|c|}
\hline $\begin{array}{c}\text { Power, } \\
\text { kWe }\end{array}$ & Application & \multicolumn{2}{|c|}{ Technology } & $\begin{array}{c}\text { Mass, } \\
\text { kg }\end{array}$ & $\begin{array}{c}\text { Area, } \\
\mathrm{m}^{2}\end{array}$ & $\begin{array}{c}\text { Volume, } \\
\mathbf{m}^{3}\end{array}$ \\
\hline \multicolumn{7}{|c|}{ Nuclear } \\
\hline $\begin{array}{l}270 \\
160 \\
30 \\
2.5 \\
4 \\
10\end{array}$ & $\begin{array}{l}\text { Habitat/bioregenerative chamber/ISRU/ } \\
\text { Optional habitat/methane plant } \\
\text { Habitat/bioregenerative chamber/ISRU } \\
\text { MTV or ERV/ERV's orbiter } \\
\text { Cargo vehicle } \\
\text { Unpressurized rover } \\
\text { Pressurized rover }\end{array}$ & $\begin{array}{l}\text { SP-100/Stirling/m } \\
\text { SP-/Stirling } \\
\text { SP-/Stirling } \\
\text { DIPS } \\
\text { DIPS } \\
\text { DIPS }\end{array}$ & rowave & $\begin{array}{r}25400 \\
14000 \\
2600 \\
230 \\
460 \\
1100\end{array}$ & $\begin{array}{r}920 \\
320 \\
40 \\
6 \\
16 \\
33\end{array}$ & $\begin{array}{r}120 \\
42 \\
23 \\
4 \\
9 \\
18\end{array}$ \\
\hline \multicolumn{7}{|c|}{ Nonnuclear (solar-based) } \\
\hline $\begin{array}{c}40 \\
40 \\
40 \\
40 \\
120 \\
120 \\
10 \\
10 \\
10 \\
4 \\
4 \\
4 \\
2.5 \\
30 \\
30 \\
2.5 \\
30 \\
30\end{array}$ & $\begin{array}{l}\text { Habitat/bioregenerative chamber } \\
\text { ISRU plant } \\
\text { ISRU plant } \\
\text { Pressurized rover } \\
\text { Pressurized rover } \\
\text { Pressurized rover } \\
\text { Unpressurized rover } \\
\text { Unpressurized rover } \\
\text { Unpressurized rover } \\
\text { Cargo vehicle } \\
\text { MTV } \\
\text { ERV/ERV's orbiter } \\
\text { Cargo vehicle } \\
\text { MTV } \\
\text { ERV/ERV's orbiter }\end{array}$ & 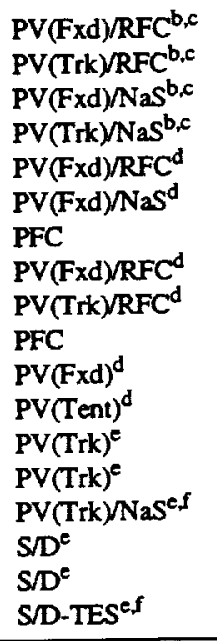 & & $\begin{array}{r}27000 \\
19000 \\
26000 \\
21000 \\
30000 \\
20000 \\
6500 \\
2900 \\
3700 \\
160 \\
150 \\
58 \\
79 \\
960 \\
1000 \\
69 \\
860 \\
950\end{array}$ & $\begin{array}{r}15000 \\
11000 \\
12000 \\
9200 \\
12000 \\
7200 \\
13 \\
1200 \\
930 \\
6 \\
100 \\
40 \\
47 \\
560 \\
560 \\
22 \\
280 \\
280\end{array}$ & $\begin{array}{c}820 \\
390 \\
640 \\
320 \\
690 \\
340 \\
29 \\
66 \\
51 \\
1 \\
5 \\
1 \\
2 \\
28 \\
28 \\
0.01 \\
.23 \\
.23\end{array}$ \\
\hline $\begin{array}{l}{ }^{2} \text { Includ } \\
\text { bPowe } \\
\text { hab } \\
\text { 'Sized } \\
{ }^{\text {d}} \text { Sized } \\
\text { 'Sized } \\
\text { 'Orbite } \\
41-\end{array}$ & $\begin{array}{l}\text { rover recharge power. } \\
\text { ystem used for a methane plant prior to } \\
\text { tion. } \\
\text { global dust storm insolation. } \\
\text { r hazy day insolation. } \\
\text { Mars orbit insolation. } \\
\text { portion requires energy storage for a } 5-\mathrm{kW} \\
\text { n eclipse of a } 123 \text {-min orbit. }\end{array}$ & $\begin{array}{l}\text { DIPS } \\
\text { ERV } \\
\text { Fxd } \\
\text { ISRU } \\
\text { MTV } \\
\text { NaS } \\
\text { PFC } \\
\text { PV } \\
\text { RFC } \\
\text { SID } \\
\text { Tent } \\
\text { TES } \\
\text { Trk }\end{array}$ & $\begin{array}{l}\text { Dynamic } \\
\text { Earth re } \\
\text { PV array } \\
\text { In-situ r } \\
\text { Mars tra } \\
\text { Sodium } \\
\mathrm{H}_{2} / \mathrm{O}_{2} \text { P } \\
\text { Photovo } \\
\mathrm{H}_{2} / \mathrm{O}_{2} \\
\text { Solar dy } \\
\text { Fixed P } \\
\text { Thermal } \\
\text { Sun-trac }\end{array}$ & $\begin{array}{l}\text { tope pow } \\
\text { vehicle } \\
\text { h fixed o } \\
\text { rce utiliz } \\
\text { r vehicle } \\
\text { or battery } \\
\text { ry fuel } \alpha \\
\text { array } \\
\text { erative fu } \\
\text { ic } \\
\text { ray in ten } \\
\text { rgy stora } \\
\text { PV arra }\end{array}$ & $\begin{array}{l}\text { system } \\
\text { ntation } \\
\text { cell } \\
\text { onfigurat }\end{array}$ & \\
\hline
\end{tabular}


TABLE III-METHANE-BASED POWER TECHNOLOGIES

\begin{tabular}{|c|r|l|l|r|r|}
\hline $\begin{array}{c}\text { Power, } \\
\text { kWe }\end{array}$ & $\begin{array}{c}\text { Time, } \\
\text { hr }\end{array}$ & \multicolumn{1}{|c|}{ Application } & $\begin{array}{l}\text { Conversion } \\
\text { technology }\end{array}$ & $\begin{array}{c}\text { Mass, } \\
\text { kg }\end{array}$ & $\begin{array}{c}\text { Volume, } \\
\mathrm{m}^{3}\end{array}$ \\
\hline 4 & 10 & Unpressurized rover & PEM FC & 150 & 0.15 \\
4 & 10 & Unpressurized rover & Stirling & 180 & .29 \\
4 & 10 & Unpressurized rover & SOFC & 120 & .18 \\
10 & 480 & Pressurized rover & PEM FC & 4200 & 11 \\
10 & 480 & Pressurized rover & Stirling & 13000 & 35 \\
10 & 480 & Pressurized rover & SOFC & 5000 & 14 \\
40 & 120 & Habitabioregenerative chamber & PEM FC & 5000 & 12 \\
40 & 120 & & Stirling & 13000 & 35 \\
40 & 120 & & SOFC & 5600 & 15 \\
40 & 1440 & & PEM FC & 48000 & 130 \\
40 & 1440 & & Stirling & 150000 & 420 \\
40 & 1440 & & SOFC & 58000 & 170 \\
\hline
\end{tabular}

aPEM FC, proton exchange membrane fuel cell.

bSOFC, solid oxide fuel cell. 
Public reporting burden for this collection of information is estimated to average 1 hour per response, including the time for reviewing instructions, searching existing data sources. gathering and maintaining the data needed, and completing and reviewing the collection of information. Send comments regarding this burden estimate or any other aspect of this collection of information, including suggestions for reducing this burden, to Washington Headquarters Services, Directorate for linformation Operations and Reports, 1215 . Jeject (0704-0188), Washington, DC 20503.

Davis Highway, Suite 1204, Arlington, VA 22202-4302, and to the Office of Management and Budget, Paperwork Peduction Project (0704-0188), Washington, DC 20503.

\begin{tabular}{l|l|l|} 
1. AGENCY USE ONLY (Leave blank) & 2. REPORT DATE & 3. REPORT TYPE AND DATES COVERED
\end{tabular}

\begin{tabular}{|l|l|l|l|l|}
\multicolumn{2}{|c}{ Technical Memorandum } \\
\hline
\end{tabular}

\section{TITLE AND SUBTITLE}

5. FUNDING NUMBERS

Power Generation Technology Options for a Mars Mission

6. AUTHOR(S)

WU-233-02-0B

John M. Bozek and Robert L. Cataldo

7. PERFORMING ORGANIZATION NAME(S) AND ADDRESS(ES)

National Aeronautics and Space Administration

Lewis Research Center

Cleveland, Ohio 44135-3191
8. PERFORMING ORGANIZATION REPORT NUMBER

E-8310

9. SPONSORING/MONITORING AGENCY NAME(S) AND ADDRESS(ES)

10. SPONSORINGMONITORING AGENCY REPORT NUMBER

National Aeronautics and Space Administration

Washington, D.C. 20546-0001

NASA TM-106451

11. SUPPLEMENTARY NOTES

Prepared for the Symposia on Space Nuclear Power Systems sponsored by the University of New Mexico, Albuquer-

que, New Mexico, January 9-13, 1994. John M. Bozek and Robert L. Cataldo, NASA Lewis Research Center.

Responsible person, John M. Bozek, (216) 433-6166.

12a. DISTRIBUTIONAVAILABILITY STATEMENT

12b. DISTRIBUTION CODE

Unclassified - Unlimited

Subject Category 20

\section{ABSTRACT (Maximum 200 words)}

The power requirements and resultant power system performances of an aggressive Mars mission are characterized. The power system technologies discussed will support both cargo and piloted space transport vehicles as well as a sixperson crew on the martian surface for 600 days. The mission uses materials transported by cargo vehicles and materials produced using in-situ planetary feed stock to establish a life-support cache and infrastructure for the follow-on piloted lander. Numerous power system technical options are sized to meet the mission power requirements using conventional and novel solar, nuclear, and wireless power transmission technologies for stationary, mobile surface, and space applications. Technology selections will depend on key criteria such as mass, volume, area, maturity, and application flexibility.

\begin{tabular}{|c|c|}
\hline 14. SUBJECT TERMS \\
Power; Mars; Nuclear; Solar \\
\hline $\begin{array}{c}\text { 17. SECURITY CLASSIFICATION } \\
\text { OF REPORT } \\
\text { Unclassified }\end{array}$ & $\begin{array}{c}\text { 18. SECURITY CLASSIFICATION } \\
\text { OF THIS PAGE } \\
\text { Unclassified }\end{array}$ \\
\hline
\end{tabular}

\begin{tabular}{|c|c|}
\hline & $\begin{array}{c}\text { 15. NUMBER OF PAGES } \\
08\end{array}$ \\
\hline & $\begin{array}{r}\text { 16. PRICE CODE } \\
\mathrm{A02}\end{array}$ \\
\hline $\begin{array}{l}\text { 19. SECURITY CLASSIFICATION } \\
\text { OF ABSTRACT } \\
\text { Unclassified }\end{array}$ & 20. LIMITATION OF ABSTRACT \\
\hline
\end{tabular}




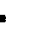

